\title{
Understanding of the Establishment and Importance of Public Relations Department in Macao: Perspectives from Governmental Officials
}

\author{
Weng Si Kuok \\ Immigration Department, Public Security Police Force \\ E-mail:wingasa@gmail.com \\ Luis Miguel Dos Santos (Corresponding author) \\ Customs Training Center, Macau Customs Service, Macau, Macau China \\ E-mail: luismigueldossantos@yahoo.com
}

Received: June 12, 2017 Accepted: June 28, 2017 Online published: July 10, 2017

doi:10.5296/jpag.v7i3.11384ＵRL: https://doi.org/10.5296/jpag.v7i3.11384

\begin{abstract}
In regard to the public relations practice with government agencies and departments, the main function of public relations consists of disseminating information. In particular, government departments often promote policies of the current administration and seek support from local residents. However, most leadership strongly believed that public relations mainly concern about gaming and hospitality industry which leading to a misunderstanding between the real responsibilities of public relations practitioners. The purpose of this research study is to understand the developments of governmental public relations tasks from the perspective of public relations professional at the governmental environment. The outcomes of this study indicated three directions: 1) The establishment of public relations division under the current government leadership; 2) The socioeconomic development of Macao and the new demand of professionals; and 3) potential challenges and limitations for government agencies in public relations. The result of this research indicated that public relations industry in Macao has a bright future, because of the fast growing on both society and economy conditions. The result may provide recommendations for governmental agencies and NGOs administrators to manage their manpower and public relations professionals into an appropriate level.
\end{abstract}

Keywords: Macao, government agencies, human resource planning, public relations 


\section{Introduction}

Macao as an international, inter-cultural and hospitality-oriented city located in southern China, after the Transfer of Sovereignty of Macau from Portuguese Republic to the People's Republic of China during the December 1999, the overall economical, commercial and social dynamic and environment had been changed rapidly. Public relations becomes an essential element among personal needs, governments, businesses, NGOs and even intra-groups communications (Sriramesh, Zerfass, \& Kim, 2013; Halff \& Gregory, 2015).

In early 2010s, the Macao governmental agency has announced an implementation of dispatch named Chief Executive number 41/2010 by the Government Spokesperson Bureau during February 2010. As for this dispatch, the government indicated that communication with the citizens is one of Government priorities. The dialogues with citizens, civil society, and the media, as well as the improvement of transparency justify the need of institutionalization of a mechanism that assures an effective and objective communication. It was well-noted that the governmental agencies understand a strong communication and public relations relationship to the residents and business in the city may increase different types of advantages. Through the described dispatch, each administrative secretary and department was designed a group of spokespersons who is now responsible for media relations and for all communications among journalists, publics, and government officials. Spokespeople are assigned to represent Macao's government as a whole, while principal officials, and bureau heads will also have individual information and public relations coordinators.

Before the announcement of this dispatch, the communication and public relation affairs were disengaged and were usually made directly between officials and journalists. As the disengagements and disconnections could increase misunderstanding to different parties, the Macao SAR Executive intended to create a central and integrated scheme to respond to the media enquiries in an effective and coherent way. Chon Weng Tam, the former chief-of-cabinet (2009-2014) of the Chief Executive Chui Sai On (2009- ), has been appointed as premier government spokesperson. Besides setting up strategies to disseminating government information and coordinating government information policy, the government spokesperson scheme also represents the government at press conferences and may be interviewed by the media. The main goal of the new scheme was to help the media with their request, and arrange suitable government officials to answer their questions. Tam stressed that the coordinators are prepared to help the media round-the-clock, especially in the instance of a serious incident. He also underlined that government officials would still be available to speak directly with the media.

Since the rapid development of information technologies, the number of available news available for publics has increased dramatically through Internet or traditional mass media. The public agencies have encountered the challenge to question the accuracy of all circulating information. Government spokesperson have then the hard task of coming out and clarifying public concerns, especially when there are rumors and a lot of speculation against the government. 


\subsection{Purpose and Significant of this Study}

Public relations professionals have a limitation for their practice in Macao's promotion, since of some local businesses and even government has not been paying enough attention to the benefits of this profession. Most leadership strongly believed that public relations mainly concern about gaming and hospitality industry which leading to a misunderstanding between the real responsibilities of public relations practitioners.

As for the current environment in Macao, more than ever, a large demand of public relations professionals to promote its overall image and to assure the continuity of Macao has an international city, with more potentialities waiting to be explored. International events, such as the Marathon, the Grand Prix, the World Women's Volleyball Campaign, the Music Festival, or the Fireworks Display Contest, have already demonstrated the importance of planned communication in attracting new visitors who are not only interested in gambling.

As for the practice of public relations, most of the manpower was concentrated in private businesses. However, under the trends of globalization, the voices of public relations have expanded its horizons and somehow considered as an essential tool for governmental departments worldwide. The single largest employer of public relations practitioners in the Macao is the government, although the government agencies typically named under other titles, including public affairs and public information. However, at the early stage of the development of this practice in governmental departments, much suspicion was around. Public relations idea was seen as a great and growing activity when practiced by businesses and was also considered acceptable for non-profit organizations, but any public relations activity by government became immediately suspect.

In regard to the practice with government agencies and departments, the main function of public relations consists of disseminating information. In particular, government departments often promote policies of the current administration and seek support from local residents. Therefore, a particular position has been created. These groups of people were usually called as public affairs specialists. These professionals perform other tasks, such as gathering information, monitoring public opinion, cooperating with top management, and motivating citizens in participating in the political process. Thus, the basic purpose of government public relations is tied to government's mission of public service, as well as the need to communicate openly and with transparency with citizens and media outlets.

\subsection{Conceptual Framework}

Fisher and Horsley (2007) explained that the concept of government public relations is extended from Grunig and Hunt's (1984) model that privileges symmetrical communication. Therefore, government can be considered as a huge sized organization, and practitioners in this area need to have more specific skills. Among the common work assignments associated with public relations in government are, for instance (1) announcing relevant information and policies related to government; (2) maintaining favorable relationships between government and local and overseas communities, and (3) persuading the publics to accept and support new policies and decisions that affect not only ordinary citizens, but organizations as a whole. 
Among these three functions, how to maintain enhance relations between government and publics is considered the most important one. Without the support from stakeholders, government may face challenges in implementing policies and is more likely to see functional problems exposed (Gregory, 2006).

\subsection{Research Question}

1) What are the understanding and developments of governmental public relations tasks from the perspective of public relations professional at the governmental environment?

\section{Literature Review}

\subsection{Understanding of Public Relations}

A number of definitions have been formulated over the years, and despite of a few differences, most of them have central elements that attempt to come out with a more standard definition of the practice of public relations. Broom (2012) defines public relations as a management function that aims to establish and maintain "mutually beneficial relationships between an organization and the various publics on whom its success or failure depends" (p. 25). According to these authors:

Every organization, no matter how large or small, ultimately depends on its reputation for survival and success ... In today's competitive market, reputation can be a company's biggest asset ... Effective public relations can help manage reputation by communicating and building good relationships with all organization stakeholders (Broom, 2012, p. 25).

Wilcox \& Cameron (2011) considered that public relations is the "strategic management of competition and conflict for the benefit of one's own organization - and when possible - also for the mutual benefit of the organization and its various stakeholders or publics" (p. 22). The Public Relations Society of America (PRSA) refers that public relations helps an organization and its publics adapt mutually to each other. Public relations is an organization's efforts to win the cooperation of groups of people.

Whatever the definition is, there are a few key words that are common in all attempts to define the practice: management function, interactive or two-way communication, an activity that is strategically planned, a research-based science, and a socially responsible action. In summary, public relations helps on strategic management of an organization in order to build, manage and improve reputation. It serves to maintain relationships between an organization and different publics (or stakeholders) through publicity, socially responsible actions, and a planned process of communication that aims to renew or create interactions with different sectors of the society. Public relations professionals are mainly responsible for building awareness for an organization with favorable stories and articles. Besides, they also manage crises that may threat the organization's image and reputation. Another field of action is the management of special events or programs intended to build goodwill among organizations and their target publics. Press releases are one of the most common tools used by practitioners in order to make announcements that are crucial for the well-being of any 
organization.

Grunig and Hunt (1984) outlines four models of public relations practice that are today helpful to identify characteristics of different practices within the field: (1) press agentry/publicity (a one-way model to advocate, with little or no research involved); (2) public information (based on journalistic ideals); (3) two-way asymmetric (scientific persuasion is its purpose), and (4) two-way symmetric (gaining mutual understanding through solicited feedback is the main purpose). Relationship management has a premise where practitioners are in the business for constructing and nurturing relationships with an organization's various publics. It builds on Grunig and Hunt's idea of two-way symmetrical communication, but goes beyond this by recognizing that an organization's publics are equal participants of an ongoing communication process, thus, they are active and interactive.

As Broom (2012) refers in his book Cutlip and Center's Effective Public Relations, organizations increasingly rely on establishing and maintaining relationship with key internal and external audiences in order to assure their survival and growth. Thus, public relations assumes the role of facilitating these relationships, as the practice aims to facilitate and maintain organizations' influence on social systems that provides publics with social and physical needs. Besides, the author identifies 10 main concepts that are related but distinct for the practice of public relations. The understanding of these concepts is essential for the practice of public relations, more specifically in recognizing the complexity of target publics: (1) employee communication or internal relations; (2) publicity (an uncontrolled way of placing messages in the media); (3) advertising (a controlled method of placing messages in the media); (4) press agentry (creating newsworthy stories and events to attract media attention); (5) public affairs (government public relations); (6) lobbying; (7) issues management (responding to issues and trends that affect an organization's relationships with its publics); (8) crisis management (strategic response to negative situations); (9) investor relations; and lastly (10) development (public relations in nonprofit organizations).

\subsection{Relationship between Public Relations and Other Subjects}

The concepts and the practical application of public relations, marketing, and advertising often are confused, due to a deficient understanding by both managers and practitioners of the differences between those three functions, and the fact that the same person may do all functions in small organizations. Some scholars consider that the major distinction between public relations and marketing is the nature of the relationships involved. While marketing is focused on relations with customers having as ultimate goal to generate financial profits to companies, public relations pays close attention to a wider range of publics and is not concerned solely with commercial interactions (Broom, 2012). Public relations goes beyond by managing the organization's reputation as a whole through a planned and strategic communication campaign.

The main distinction between advertising and public relations relies on the control of the produced media. In the case of publicity - the main approach of public relations practitioners in obtaining favorable opinion - professionals have little or no control over what happens to their press releases (Broom, 2012). However, practitioners can control their messages in 
advertising, since they buy space or time in media for so, and they have the last word about the content that will be printed or broadcasted. While publicity is considerably cheap since it basically relies on extensive use of press release and special events, advertising costs more money to organizations and sometimes it is not considered as beneficial - publics will trust more on a news written or broadcasted based on a press release than on an advertisement or commercial that was paid to be disseminated. Moreover, most advertising messages intend to sell goods and services to customers targeted by marketing, but in the case of public relations tools, messages are created to reach a wider range of publics, creating awareness about organizations and ultimately influencing their purchase decisions. Other non-marketing advertising include its use by human resources to announce job openings, legal departments to conform to legal requirements or to recalls of defective products.

\subsection{Development of Public Relations Industry}

Although the demand is increasing, the education of public relations is just beginning. Ethics in the professional has been one of the greatest concerns. Every profession has a code of ethics, which provides guidelines and educate professionals how they should act in their role. The major principle of professional ethics is the imperative of trust, in order words, practitioners should behave ethically to protect the profession itself and their own position of privilege (Heath, 2000). According to Broom (2012) socially responsible public relations has a positive consequence, such as improving professional practice and the conduct of organizations by emphasizing the need for public approval; replacing misinformation with information, and helping organizations and publics adapt to changing.

The U.S. Bureau of Labor (2013) indicates that employment of public relations specialists is expected to grow 23 percent from 2010 to 2020, faster than the average for all occupations. The mains requirements for candidates are a bachelor's degree in Public Relations, Marketing or related field; at least three years of public relations experience in a corporate or agency setting, and excellent verbal and writing skills. The median annual wage of public relations specialists was US\$52,090 in May 2010. The U.S. Bureau of Labor Statistics also indicates that employment of public relations managers is expected to grow 16 percent from 2010 to 2020 , about as fast as the average for all occupations. They are required to have more than five years working experience in public relations field. The median annual wage of public relations managers was US $\$ 91,810$ in May 2010. Salary is positively influenced by previous experience in the field, influence on the decision-making process, and participation on the overall organization's management process (Dozier \& Broom, 1995). Likewise, growing opportunities are not only noted in the U.S., but also around the globe as the public relations field develops into a more specialized profession. This growth is driven, above all, to the need of maintain public image and match with the growth of social media. One of the main obstacles for public relations practitioners is the need to be proficient in a variety of skills. A 2010 survey conducted by the Institute for Public Relations (IPR), an independent nonprofit foundation dedicated to the science beneath the art of public relations founded in 1956 in the U.S., predicts that the top duties for public relations managers in 2015 will be connecting communication strategies to overall organizational goals, and opening up space for new strategies that go beyond the simple use of publicity. 


\section{MInstitute ${ }^{\text {Mech }}$}

Journal of Public Administration and Governance

ISSN 2161-7104

2017, Vol. 7, No. 3

There are at least 10 main working assignments that require public relations professionals a complex and elaborate body of knowledge for exercising this profession. Scholars (e.g. Heath, 2000; Seitel, 2011; Broom, 2012; Wilcox et al., 2011) identify writing, editing and speaking as the most important tasks, followed by media relations and placements, ability to conduct both primary and secondary research, management, organizing special events, counseling management, and training. Thus, the profession requires specialized education to acquire a body of knowledge and skills based on theory developed through research.

Depending of the educational background, working experience, and personal abilities, practitioners assume different organizational roles. According to Broom (2012), four role models describe the patterns of behavior adopted by practitioners. The first category is the communication technician, who typically implements program tactics determined by others, without assuming any role in strategic planning. Secondly, the expert prescriber, who assumes a very active role in making decisions, while organization entrust the practitioner having a very passive role. The third category is the communication facilitator, who maintains two-way communication and facilitates discussion. Lastly, the problem-solving facilitator collaborates with other managers to define and solve problems, especially in crisis management situation.

\subsection{The Emergence of Public Relations as an International Profession}

The U.S. Bureau of Labor Statistics estimated public relations employment to be 331,900 in 2010 , with more than 341,000 practitioners expected by 2018. The growth of public relations is not restricted to the United States; it's a worldwide phenomenon. The Global Alliance estimates that 3 million people worldwide practice public relations as their main professional activity. Public relations is growing as a field in terms of employees and revenues, and its growth is expected to continue because of the increasing number of students majoring in public relations worldwide. For instance, American organizations spend an estimated \$3.7 billion U.S. dollars annually on public relations and related ventures, which continues to grow as well (Wilcox and Cameron, 2011).

Macao is not an exception in this worldwide growth trend. Since the establishment of the Special Administrative Region of Macao, in 20 December 1999, the city has experienced very rapid tourism and economic growth that has a direct impact on the need of public relations professionals. Macao is the only place in China where gambling is considered legal and the first decade of 2000 was marked by the liberalization of the casino licensing system (2002), bringing to the city overseas casino concessionaries that have streamlined competition, and, more importantly for this study, have highlighted the importance of the practice of public relations as a management function essential to enhance reputation and keep favorable interactions with various stakeholders groups.

Stone (2005) pointed out that there are more companies and other organizations that are increasingly aware of their responsibilities to the community. On the other hand, publics affected by those organizations also understand that what a company does and says may improve or damage its image and reputation. As organizations grow more globalized, multinational trading has brought producers and consumers closer than before. Public 
relations professionals play a critical role in the interaction of world-class organizations with new host communities, since these practitioners may provide expert insights helpful to understand different backgrounds and cultures, solving problems in an efficient way in order to build a positive image of an organization.

\subsection{Educational Background of Public Relations Study in Macao}

A bachelor's degree specifically in the public relations field is highly advisable in Macao. The territory has 10 higher education institutions, but only the Macao Polytechnic Institute offers specific training in the field of public relations. The University of Macao, the Macao University of Science and Technology, and the University of Saint Joseph offer general communications program with a few courses focused on the practice of public relations. However, the bachelor's degree of arts in public relations of the Macao Polytechnic Institute is designed to offer solid and broad training for future professionals.

Before 2010, the Macao Polytechnic Institute provided only a higher diploma for public relations. After gaining the diploma, students could follow an extra year of supplementary courses in order to receive the bachelor in management. In academic year 2010-2011, the institution set up its first undergraduate program for public relations. The program is designed in accordance with the curriculum suggested by the Public Relations Society of America. According to the advice from Public Relations Society of America and the information of Macao Polytechnic Institute, it contains general study such as foreign languages, English writing, business disciplines, such as Introduction to Business, Strategic Management, Principle of Marketing, Accounting, and Statistics and so on. One core component of the bachelor degree is the communication studies in courses such as Principles of Public Relations, Public Communication Skills, Public Relations and Marketing Research, Public Relations Cases and Campaigns, and Public Relations in the Global Environment. At the end of the degree, students can obtain a total of 145 credits, all of them somehow related to the practice of public relations.

\section{Methodology}

\subsection{The Application of Qualitative Research Method and In-Depth Interviews}

This research study seeks to answer one research question about the public relations issue in the government sector in Macau. In order to gather meaningful data information about the understanding and opinions about the public relations industry within the governmental environment in Macao, the researchers decided to employ a qualitative research method with the tool of in-depth interview (Merriam, 2009). In-depth interview tool allows the researchers to gather first-hand and meaningful verbal information from the targeted participants.

Firstly, the researchers sent an invitation letter to 10 participants in total for the purpose of this study. Eventually, 8 out of 10 participants were agreed to participate to this study.

Secondly, the researchers arranged a one-to-one and individualized interview with each participant. The interviews mainly took place in the office of each participant. During the interview with each participant, the researchers record all the voice recording with a digital 
cellphone. All the voice recording were all transcripts from voice messages to written transcripts (Merriam, 2009).

Thirdly, the researchers read all the transcripts of each participant and narrowed down the meaningful information into categories via the General Inductive Approach (Thomas, 2006). Detailed information is outlined at the below section.

\subsection{Participants}

A purposive sampling strategy (Creswell, 2008) was employed to invite 8 civil servants in the public relations sector. Participants' demographic information, such as name, gender, years of experience, and educational background were collected. However, the identification of participants will be pseudonym in order to protect the privacy.

Table 1. Biography of participants

\begin{tabular}{|c|c|c|}
\hline $\begin{array}{c}\text { Name } \\
\text { (Pseudonym) }\end{array}$ & $\begin{array}{l}\text { Years of } \\
\text { Experience }\end{array}$ & Education \\
\hline Amy & 8 & $\begin{array}{l}\text { Bachelor of Art in Chinese Language and } \\
\text { Literature }\end{array}$ \\
\hline Betty & 8 & Bachelor of Arts in Public Relations \\
\hline Cathy & 6 & Bachelor of Arts in Public Relations \\
\hline Daniella & 7 & $\begin{array}{l}\text { Bachelor of Social Sciences in Public } \\
\text { Administration }\end{array}$ \\
\hline Eddie & 12 & $\begin{array}{l}\text { 1) Bachelor of Art in Communication } \\
\text { 2) Master of Public Administration }\end{array}$ \\
\hline Freddy & 15 & $\begin{array}{l}\text { 1) Bachelor of Arts in Public Relations } \\
\text { 2) Master of Public Administration }\end{array}$ \\
\hline Gino & 4 & Bachelor of Arts in Public Relations \\
\hline Harrison & 5 & Bachelor of Arts in Public Relations \\
\hline
\end{tabular}

\subsection{Analytical Procedure}

General Inductive Approach was employed in this particular study. General Inductive Approach (Thomas, 2006) allowed the researchers to narrow down a large number of interview transcripts and information into meaningful themes in order to answer the research question. The researchers decided to employ General Inductive Approach due to the simple 
applications and limitations.

Firstly, the researchers read through all the transcripts carefully. Secondly, the researchers divided and categorized several meaningful sentences and words into 30 categories. Thirdly, the researchers continued to narrow down the large-sized categories into 3-5 meaningful themes.

\subsection{The Protection of Human Subject Information}

The personal information of all participants must be highly protected. As some of the interview data information may involve with sensitive ideas and opinions, the researchers decided to provide each participant with pseudonym in order to protect the personal information. In addition, all the related data information must be locked in a password-protected computer. Only the researchers had the log-in information.

\subsection{Interview Language Use}

Both the researchers and participants are native Cantonese speakers. As most of the participants cannot use fluent English to express their understanding, opinions and ideas during the interview, the participants were allowed to use Cantonese to conduct the interview. After the interview, the researchers translated all the interview records and transcripts from Chinese to English in order to complete this research study.

\section{Finding and Discussions}

The researchers have interviewed 8 participants for this study in order to address our research question. The research question of this study is:

After an effective data analysis procedure, the researchers categorized 3 themes. These themes are: 1) The establishment of public relations division under the current government leadership; 2) The socioeconomic development of Macao and the new demand of professionals; and 3) potential challenges and limitations for government agencies in public relations.

\subsection{The Establishment of Public Relations Division under the Current Government Leadership}

Amy has referred that her government agency established the Division of Communication since the current governmental leadership (around 6 years ago). At least two participants in the government field said the Public Relations divisions or sectors has been running for at least 5 years, while others referred to less time, such as between 3 and 7 years. Regarding this topic, Eddie added that:

Our division has been set up four years ago. Before that, we had just one person in charge for the public relations' work, but now we have more people specialized in this field, and we currently have a team with 5 public relations practitioners.

Basically, all participants from government agencies agreed on two main reasons for the creation of Public Relations sectors: firstly, being a government agency, the main goal is to 
provide excellent service to residents and visitors in Macao. Secondly, to assess opportunities brought by Macao's recent socioeconomic development in fulfilling the demand of public relations market. For instance, Freddy told us that, "The government's goal is to provide professional public relations services to clients in different sectors and industries, in order to solve their problem with human resources shortage."

On the other hands, three participants - Gino, Harrison, and Daniella - who expressed that their Public Relations divisions or sectors were established with the main purpose of enhancing communication between their agency and publics. Moreover, most participants in the pointed out that their divisions or sectors were created under the assumption of promoting a positive image and improving their reputation among different key publics (media, community, investors, employees, and government relations). Cathy told us that:

Our department's goal is quite clear. We, as public relations practitioners, are responsible for keeping and improving the reputation and the good image, and to make the department stand out, building and maintaining goodwill especially in the field of media relations.

Moreover, Amy added that the purpose for setting up her department's public relations division was to maintain a beneficial relationship with media outlets, as a means to make sure that messages were channeled out widely, positively, and timely.

Betty pointed out that her Public Relation sector was establish as a way to promote exchange and cooperation between Macao and Taiwan tourism's agencies, as well as to strength communication ties for developing technology and environmental protection, education, health, culture, creativity, academic publishing, technical, or social welfare. According to Daniella, the concept of government's spokespersons scheme was delineated in order to promote a transparent image of local government, while Gino expressed the importance of promoting the image of Macao as an international city able to attract tourists from all over the world.

\subsection{The Socioeconomic Development of Macao and the New Demand of Professionals}

The strong socioeconomic development of Macao in the decade has boosted the demand for public relations professionals, and all our participants agreed that Macao encounters a shortage of qualified human resources in this field, what has been limiting the potential growth of the profession in the region. In that sense, Cathy said that:

Due to the increase of population with higher education level, fresh graduates of public relations or related areas are fulfilling the basic needs of the market. Yet, experienced and talented public relations professionals are still a shortage in the labor market. Therefore, most of the management levels of the public relations departments are hired from other fields or academic majors. Thus, for entry-level positions the situation is not dramatic, but it becomes more complicated for higher positions...

The latest technological development also seems to have influence on the contemporary 
practice of public relations. Most participants mentioned that the field in Macao has changed since they first started working, and that day after day their roles are becoming more challenging due to the appearance of new technologies. The participants explained that technology has created a new way to communicate with publics, enlarging their job scope and requirements to succeed, but at the same time as create more barriers for professionals since now there is a large pool of tools that have to be monitored in order to keep track on organizations' performance and reputation.

All participants mentioned both of these problems as the major obstacles for the practice in Macao. All agreed that it is necessary to invest more on higher education in order to recur to local talents instead of recruiting professionals from other regions and countries. As Betty mentioned:

With the expansion of the non-governmental industry, we don't have enough public relations professionals to best represent the department. As there are so many different aspects within one corporation and industrial field, it takes public relations professionals who specialize in different fields to deliver the best work in non-governmental field. But it's not easy to find local resources for so many positions.

Amy added that this lack of local talents can reduce the pace of Macao development in the field of public relations:

We should provide more educational support for youngsters who want to join this career. The local workforce could be well trained to meet up our current needs. Personally, I think the two are closely related and each will not be well-developed without the other. That is, if the workforce cannot accommodate the development of Macao, it results in a slower pace of development and vice-versa; if the development is too slow, existing workforce will definitely be enough.

Participants agreed that public relations is the one that faces more challenges in finding human resources, since they are, at the same, the largest job suppliers for this field. With the announced development of new tourism and gaming resorts in Macao, the demand for public relations practitioners is expected to even double, especially because many organizations will keep hiring third-party agencies to collaborate with them in order to solve their human resources shortage.

More than half of the participants thought that the liberation of gaming industry and the booming of tourism industry are the main reason for the demand increasing of public relations. Such gaming and hospitality competitors also take a large number of qualified public relations professionals away from the government agencies. As Eddie told:

The Cotai projects influenced Macao a lot on economic and social development, bringing along with the development of tourism industry. Companies concerned more about their reputation or image. Because of the economic development, people have more chances to study in different fields and more and more people 
choose public relations as their major because they know that the demand is now increasing. However, as there are more selections other than the government, many of the public relation graduates decide to join the private agencies instead.

The Meetings, Incentives, Conferences and Exhibitions industry (MICE) was also mentioned by participants as another booster for the development of the public relations field in the region. The establishment of international companies, casinos, resorts, and organizations in Macao, with a new business culture and through prioritizing the importance of public relations, is another factor that has contributed to a higher demand of professionals in the last ten years. As Daniella said:

There are several international projects developing in Cotai Strip, Hengqin island, Hong Kong-Zhuhai-Macao Bridge that need a lot of experts and workforce to support. I'm anxious about the potential work force is not enough to support the project as the Executive of Sands China Limited mentioned recently.

As government has been increasing its focus on policies related to the development of the MICE, and the Cultural and Creative industries, practitioners forecast that even a higher demand of public relations professionals will force the recruitment of experienced workforce. Cathy explained that:

The policies are just bringing up the economy of Macao, not really the impact to the professionals. One thing you can say is the demand becomes higher because of the development of MICE, Cultural and Creative industries.

In summary, both of the government and private agencies have already understood the importance of public relations for promotional and marketing purposes. Due to the rapid socioeconomic development, the public relations junior and senior professionals would be one of the highest needs manpower in this decade.

\subsection{Potential Challenges and Limitations for Government Agencies in Public Relations}

Participants also referred that it is still not easy today to attract residents and visitors to use some of the e-government services. One of the primary goals for the current government is to promote electronic services for all residents and visitors, particularly for senior residents who may not able to come to the government centers. As Harrison expressed:

To maintain the quality of performance towards residents is the first challenge to us. Secondly, we have to attract more residents to use our convenience services, such as e-government service, trying to convince them that our government can provide them the best services.

Gino also pointed out the absence of experience professionals in public relations is the main challenge at this moment, while other 2 participants referred that as there are more and more public relations private organizations working in Macao, it makes the government more difficult because there is now more competitions. Other 6 participants also said that the lack of knowledge about their profession is another common problem they face in Macao. Being a new profession in the region, these participants believed people usually misunderstand their roles 
and responsibilities, confusing their functions with marketing, advertising, or even modeling.

All of the participants, however, suggested that providing a high quality education in this field is the best way to make this profession more respected and better accepted in Macao. Eddie said, for example, that the way is not easy, and it is necessary to offer opportunities for new talents to grow:

Lack of practical public relations knowledge is a huge problem. Even myself, I don't have enough experience about how to handle public relations issues. As I remember, the first 3 months when I joined in the government, I totally didn't know how to write a press release. No one has full knowledge of public relations. We just can learn by doing.

Another participant also referred that it should be created a kind of an official accreditation agency for public relations in Macao, as a way to make the qualifications more demanding and to keep high ethical standards.

In summary, participants demonstrate that their motivations for entering this field are varying. In government agencies, most practitioners have become public relations due to their department's reorganization and an increasing need to improve transparency in communication, and public relations was not their primary choice.

In the case of government public relations, this importance relies mainly on making government's policies and performance more transparent and believable. Participants think that the major role of public relations is to create a bridge between their department and different publics that are somehow related to their businesses. As most participants have referred to, the most important task is to maintain beneficial and mutual relationships with target audiences. No matter what the audience is, practitioners are concerned about the image their organizations have on publics. The term public relations still may create misunderstandings, since this is still a quite new profession in Macao. Participants of this study recognize that the practice is usually confused with marketing, advertising, or even modeling. However, as it has become more known, the researchers believe that these misunderstandings are likely to be minimized in the future.

The socioeconomic development of Macao has increased the demand of public relations practitioners in all industries in the decade. However, this potential growth is challenged, above all, by both lack of human resources and lack of experienced professionals who could occupy higher job positions within the public relations departments. Practitioners believe that it is necessary to provide more specialized education, as well as increase the quality of graduates in order to meet the field requirements. The rapid development of Macao's economy makes more companies and government agencies to need talents in this field. Therefore, there are not enough talents to fulfill all positions offered in Macao. 


\section{Conclusion}

As public relations in government departments are not focused on profits, practitioners in this field concentrate their efforts on how to promote policies from government to publics and that is why the government needs to have public relations departments. In addition, public relations in government departments play an important role between the publics and government, since publics will give their request and opinion to the government through the government public relations.

The technological development that has changed the way of government agencies now communicate with internal and external target publics, as well as the requirement of broader and deeper knowledge not only of communication tools, but also of management and business disciplines.

As for the potential limitations, the researchers acknowledge that qualitative methods allowed working with small samples of participants in order to obtain their views in deeper details and extent. But it can also affect the application of the results since the findings cannot be generalized. Furthermore, there is no previous research made about the practice of public relations in Macao, what constitutes a shortcoming for our study, since the researchers had to recur to primary research to obtain the data and there is no parameter to compare with. As a way to deal with this obstacle, all secondary sources are based on the literature provided by overseas scholars where public relations research seems to be more developed and active.

In conclusion, the development of public relations industry in Macao has a bright future, because of the fast growing on both society and economy conditions. However, the researchers consider that is important to develop further and deeper studies about this practice in Macao, in order to help public relations professionals to have a clear direction in their future development, helping the profession to understand their importance and encouraging practitioners to be more proactive from the professional standpoint in order to fulfill the high demand of public relations professionals in Macao.

\section{References}

Broom, G. M. (2012). Cutlip and center's effective public relations (11 ${ }^{\text {th }}$ ed.). New York: Pearson.

Cheng, C. M. B. (1999). Macau: A cultural janus. Hong Kong: Hong Kong University Press.

Creswell, J. W. (2007). Qualitative inquiry and research design: Choosing among five approaches $\left(2^{\text {nd }}\right.$ ed.). Thousand Oaks: Sage.

Dozier, D. M., \& Broom, G. M. (1995). Evolution of the manager role in public relations practice. Journal of Public Relations Research, 7(1), 3-26.

Fisher, B., \& Horsely, J. S. (2007). The government communication decision wheel: Toward a public relations model for the public sector. Journal of Public Relations Research, 19(4), 377-393.

Gregory, A. (2006). Adevelopment framework for government communicators. Journal of Communication Management, 10(2), 197-210. 


\section{Macrothink}

Journal of Public Administration and Governance ISSN 2161-7104 2017, Vol. 7, No. 3

Grunig, J. E., \& Hunt, T. (1984).Managing public relations. New York: Holt, Rinehart and Winston.

Halff, G., \& Gregory, A. (2015). What is public relations to society? Toward an economically informed understanding of public relations. Public Relations Review, 41(5), 719-725.

Heath, R. L. (2000). Handbook of public relations. Thousand Oaks, California: Sage Publication.

Merriam, S. B. (2009). Qualitative research: A guide to design and implementation. San Francisco: Jossey-Bass.

Seitel, F. P. (2011). The practice of public relations. Saddle River, NJ: Prentice Hall/Pearson.

Sriramesh, K., Zerfass, A., \& Kim, J.N. (2013). Public relations and communication management: Current trends and emerging topics. New York: Routledge.

Stone, J. D. (2005). Public Relations and Public Responsibility. Public Relations Quarterly, $50(1), 31-34$.

Thomas, D. R. (2006). A general inductive approach for analyzing qualitative evaluation data. American Journal of Evaluation, 27(2), 237-246.

United States Department of Labor, Bureau of Labor Statistics. (2013). Occupational Outlook handbook: Public relations managers and specialists. Retrieved 19 September 2013 fromhttp://www.bls.gov/ooh/Management/Public-relations-managers-and-specialists.htm.

Wilcox, D. L., \& Cameron, G. T. (2011). Public relations: strategies and tactics. Boston, Mass.: Allyn \& Bacon.

\section{Copyright Disclaimer}

Copyright for this article is retained by the author(s), with first publication rights granted to the journal.

This is an open-access article distributed under the terms and conditions of the Creative Commons Attribution license (http://creativecommons.org/licenses/by/4.0/). 